\title{
Role of Plant Growth-Promoting Rhizobacteria (PGPR) and Bio-Control Agents (BCAs) in Crop Production
}

\author{
Sujata Kumari, Narender K. Bharat and Ashok K. Thakur
}

Dept. of Seed Science and Technology, Dr. Y. S. Parmar University of Horticulture and Forestry, Nauni, Solan. H.P. (173 230), India

\section{Corresponding Author}

Sujata Kumari

e-mail: sujatasst1990@gmail.com

\author{
Article History \\ Article ID: IJEP00379 \\ Received in $08^{\text {th }}$ July, 2020 \\ Received in revised form $24^{\text {th }}$ July, 2020 \\ Accepted in final form $17^{\text {th }}$ August, 2020
}

\begin{abstract}
The bioagents like Plant Growth Promoting Rhizobacteria (PGPR) and Biocontrol Agents (BCAs) play a crucial role in plant growth promotion, nutrient uptake and suppression of biotic and abiotic stresses. Different researchers have applied these bioagents by various means either through seed treatment or through soil application to prevent various plant diseases. Thus, these non-chemical environment friendly tools can be exploited to enhance crop production.
\end{abstract}

Keywords: BCAs, Rhizobacteria, seed and soil application

\section{Introduction}

The world population is increasing rapidly and feeding this huge population is a real challenge in upcoming time, an endeavor that requires resolving the issue is increased agricultural productivity. Besides, now-a-days people are more aware chemical hazards and benefits of organic produce on their organoleptic and nutritional properties. Hence, use of non-chemical environmental friendly tools for crop production and plant disease management became more popular in agriculture.

PGPR (Plant Growth Promoting Rhizobacteria), a group of plantbeneficial rhizobacteria, potentially beneficial for stimulating plant growth and increasing crop yields. In the last few years, the number of PGPRs has been found to increase mainly due to their role in the rhizosphere. Various species of bacteria such as Pseudomonas, Azospirillum, Azotobacter, Klebsiella, Enterobacter, Alcaligenes, Arthrobacter, Burkholderia, Bacillus and Serratia have been reported to enhance the plant growth and suppress phytopathogens (Saharan and Nehra, 2011). Another group of beneficial microbes are fungal species (Trichoderma) well-known biological control agents (BCAs) and are now formulated and used extensively to prevent several soil borne plant diseases. Trichoderma species are successful antagonists having biocontrol abilities against economically important plant parasitic soil-borne pathogens and present abundantly in almost all type of soils (Kushwaha and Verma, 2014; Olabiyi and Ruocco, 2013; Shahid et al., 2014).
Biocontrol antagonists played important role in the management of plant diseases and parasitic microorganisms (Alwathnani and Perveen, 2012; Hajieghrari et al., 2008; Zhang et al., 2013). Trichoderma attacked other plant pathogenic fungi and promotes plant and root growth. It uses different mechanisms for the control of plant pathogenic pathogens including antibiosis, mycoparasitism, the induced resistance of host cell and competition for nutrient and space. Species of Trichoderma can control and antagonize broad range of economically important postharvest phytopathogenic fungal pathogens and plant-pathogenic fungi as well as also control bacteria and viruses (Harman 2006; Yedidia et al., 2003). Trichoderma spp. also enhances plant growth and root development (biofertilizer) and stimulates plant defense mechanisms (Harman et al., 2004). Some Trichoderma strains have been shown to penetrate the epidermis and establish robust and long lasting colonization of root surfaces.

\section{Effect of Seed Treatment with PGPR and BCAs on Crop Production}

Plant growth, yield as well as seed quality parameters viz., germination, seedling vigour index, plant height, plant dry weight, number of fruits/plant, fruit weight and fruit yield (1080.00 g plant $^{-1}$ ) in chilli was enhanced with PGPR application (Kanchana et al., 2014). The indigenous isolates of PGPR showed significant plant growth promotion with respect to increase in root and shoot length and number of secondary roots as compared to control under glasshouse 
conditions (Kumar et al., 2011) as well as plant growth and yield attributes such as total number of fruits and fruit weight under field conditions in chilli (Datta et al., 2011). Similarly, indigenous PGPR were efficacious as seed treatment in capsicum w.r.t. improvement in yield and soil health (Gupta et al., 2015). In bell pepper, Mandyal et al. (2012) observed highest shoot length, plant biomass, root biomass, number of fruits/plant and yield after seed inoculation with a Bacillus isolate (PM9) over untreated control. The seed treatment not only improved plant growth and yield but also reduced the incidence of major diseases of chilli crop plant. Bacillus subtilis KP07 elicited induced systemic resistance (ISR) against Colletotrichum acutatum and recorded minimum disease severity when compared to chemical control, whereas the disease severity of Phytophthora capsici was recorded $60 \%$ in KP07 treated plants when compared to chemical control (80\%) (Suh et al., 2011). PGPR mixed bioformulation, Pseudomonas fluorescens $1+B$. subtilis + neem + chitin as the best treatment for reducing the fruit rot incidence besides increasing the plant growth and yields parameters under both greenhouse and field conditions in chilli. There was manifold increase in chitinase, 6-1, 3 glucanase, peroxidase, polyphenol oxidase, phenylalanine ammonia lyase and phenol accumulation in plants treated with mixed formulation (Bharathi et al., 2004). The incidence of Fusarium wilt in red chilli (Capsicum annuum L.) seedlings was observed relatively reduced due to chitinolytic bacteria as a biocontrol agent (Suryanto et al., 2010). A rhizobacterial isolate $A B 17$ induced the greatest increase in plant height, root length, shoot fresh weight and root biomass under greenhouse conditions when applied as seed treatment @ 108-109 in pepper (Lamsal et al., 2012). The PGPR strains viz., Bacillus amyloliquefaciens IN937a, B. subtilis GBO3 and Brevibacillus brevis IPC11 showed enhancement in the seed quality parameters like seed germination and seedling vigor and reduction in bacterial canker disease when applied as seed treatment (Girish and Umesha, 2005). Inoculation with $B$. subtilis BEB-ISbs (BS13) increased fruit weight and length, yield and enhanced texture of tomato fruits (Violante and Portugal, 2007). Whereas, Mangmang et al. (2014) reported that PGPR inoculate @ $10^{-11} \mathrm{cfu} \mathrm{m}^{-1}$ in tomato and lettuce seeds produced longer and heavier roots with superior germination and vigor. The lipopeptides, especially surfactin and fengycin produced by Bacillus subtilis strains are able to stimulate bean and tomato plants and also decreased the impact of subsequent pathogen infection (Jourdan et al., 2007). Pseudomonas syringae pv. tomato (bacterial speck of tomato) and Azospirillum brasilense resulted in decreasing the population of Pseudomonas, eliminating disease development and improving the plant growth (Bashan and Bashan, 2002) The application of biofertilizers, Rhizobium, Azotobacter and phosphate solubilizing bacteria (PSB) increased plant height $(45.26 \mathrm{~cm})$, number of nodules/plant (38.46), yield of grain and straw of field pea (Rather et al., 2010). PGPR inoculation as seed coating @ $1.5 \times 10^{9} \mathrm{cfu} \mathrm{ml}^{-1}$ in runner bean increased photosynthesis, transpiration, water use efficiency and leaves chlorophyll content and grain yield (Stefan et al., 2013). Whereas, Amin et al. (2014) reported that seed treatment with Pseudomonas fluorescens (talc formulation $10 \mathrm{~g} \mathrm{~kg}^{-1}$ to soak the seeds in 1 litre of water for 24 hrs) decreased anthracnose symptoms in common bean and consequently achieved greater yield. Rhizobacterial inoculants (Pseudomonas putida NWU12, P. fluorescens NWU65, Vibrio fluvialis NWU37 and Ewingella americana NWU59) when applied as seed treatment @ $10^{6} \mathrm{cfu} \mathrm{ml}^{-1}$ increased plant height in spinach and pepper over the control (Hou and Oluranti, 2013). Application of three PGPR strains (Azotobacter sp., Nitrobacter sp. and Nitrosomonas sp.) was found to increase seed germination, plant height, stem width and root length in Piper nigra plants (Ibiene et al., 2013).

Bacillus megaterium with B. megaterium TV-91C @ $1 \times 10^{8}$ cfu $\mathrm{ml}^{-1}$ in cabbage increased fresh and dry shoot and root weight as compared to untreated control (Turan et al., 2014). Khalid et al., 2004 reported that seed inoculation with selected PGPR isolates exhibited stimulatory effects on grain yields of wheat with $7 \%$ increase over control in pot and up to $5 \%$ increase over control in field experiments. Seeds of wheat inoculated with $8 \mathrm{~N}-4$ isolate of Bacillus pumilus @ 10 $10^{6}-10^{7}$ $\mathrm{cfu} \mathrm{ml}^{-1}$ recorded maximum increase in shoot biomass, root length, total nitrogen and phosphorous contents (Hafeez et al., 2006). Similarly, seed inoculation of bacterial strains (Pseudomonas putida and Azospirillum lipoferum @ $10^{8} \mathrm{cfu}$ $\mathrm{ml}^{-1}$ ) significantly enhanced seed germination and seedling vigour, plant height, 100 seed weight, number of seed/ ear and leaf area and shoot dry weight in maize (Gholami et al., 2009). Pseudomonas fluorescens and Pseudomonas putida in maize increased germination percentage, vigor index, plants circumferences, number of leaves and the leaf area and aerial dry matter (Noumavo et al., 2013). Two isolates of PGPR (Bacillus and Azotobacter) increased seed germination, number of leaves and seedling vigour in maize when applied as seed treatment @ $10^{8} \mathrm{cfu} \mathrm{m}^{-1}$ (Sengupta et al., 2015). Inoculation of Azospirillum increased maize productivity and cob length (Casanovas et al., 2000). Whereas, a combined inoculation of Pseudomonas and Bacillus @ $10^{8}$ cfu $\mathrm{ml}^{-1}$ as seed treatment increased plant height and dry weight in maize plants (Jarak et al., 2012). Bacterial isolates of Agrobacterium, Bacillus, Enterobacter and Pseudomonas inhibited mycelia growth of Phytophthora cactorum and $P$. fragariae var. fragariae in strawberries (Hessenmeller and Zeller, 1996). Dual inoculation of PGPR strains improved growth and tuber yield of potato under field conditions (Sunaina and Ajay, 2005). Application of Azospirillum + Phosphobacteria recorded less number of days to appearance of first female flower and narrower sex ratio as compared to control in cucumber (Nirmala et al., 1999). Azospirillum strains viz. ACD-15 and ACD-20 significant increased grain yield in sorghum over the control (Alagawadi and Krishnaraj, 1998). Inoculation of soybean plants with PGPR in the presence of 
B. japonicum increased grain yield, grain protein yield, and total plant protein production under short season conditions in Canada (Dashti et al., 1997). Seed inoculation with T. viride showed the highest germination $(96.29 \%)$ and the rate of seedlings emergence (5.73) as compared to control in sweet pepper under greenhouse conditions (Diniz et al., 2009). Among the five Trichoderma strains, $T$. harzianum gave the highest germination percentage both in laboratory and field conditions in chilli (Asaduzzaman et al., 2010). Sriram et al. (2009) reported that the elicitor treatment as seedling dip reduced $P$. capsici infection to $23 \%$ compared to control (93\%) in chilli. Mehetre and Kale (2011) recorded $83.16 \%$ inhibition of disease with respect to infected control pots. $T$.

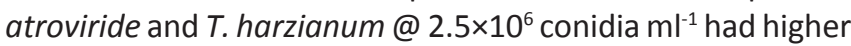
emergence percentage and lower disease incidence (Olawumi et al., 2016). The combination of Pseudomona fluorescens $+T$. harzianum as a better seed bio-priming option for increasing growth and reducing damping off in capsicum nursery (Kumar et al., 2010).

Seed treatment with $P$. fluorescens and $T$. harzianum were more effective in increasing the seed germination and vigour and reducing anthracnose disease in capsicum even than the fungicide seed treatment (Raj and Christopher, 2009). Duc et al. (2017) reported that combined inoculation of PGPR $\left(10^{8} \mathrm{cfu} \mathrm{m}^{-1}\right)$ and Trichoderma $\left(10^{7} \mathrm{cfu} \mathrm{ml}^{-1}\right)$ at seedling stage improved yield parameters of three pepper varieties (Karpex, Karpia and Kaptur) under field conditions.

\section{Effect of Soil Application with PGPR and BCAs on Crop Production}

The effect of soil application with PGPRs on plant growth, yield and disease management has also been observed by various workers. Kokalis et al. (2002) evaluated tomato and pepper transplants amended with formulations of several PGPRs and found improved seedling growth, vigour and survival of such plants in the field. The artificial inoculation of rhizobacteria, Azospirillum caused a positive effect on tomato plant growth and yields (Glala et al., 2010). The incidence of diseases i.e. powdery mildew, leaf spot, wilt and dieback was significantly reduced in PGPR treatment @ $10^{8} \mathrm{cfu} \mathrm{ml}^{-1}$ as compared to un-inoculated ones in chilli (Naik et al., 2011). The direct promotion of plant growth by soil application of PGPR generally entails providing the plant with a compound that is synthesized by the bacterium or facilitating the uptake of nutrient from the environment (Glick, 1995). P. fluorescens strains increased the root length and root area in the treated by producing plant growth hormone viz., IAA and GA (Dibypaul et al., 2005). Soil treatment with Azospirillum ( $2 \mathrm{~kg} \mathrm{ha}^{-1}$ ) along with nitrogen took less number of days for first flowering compared to application of $\mathrm{N}$ alone in rice (Balasubramaniam and Kumar, 1989). T. harzianum inoculated chilli plants showed significant increase in plant growth parameters like shoot length, root length, dry weight of shoot and root, number of leaves and number of branching as compared to control (Bhuvaneswari et al., 2014). Soil application with $T$. harzianum, $P$. fluorescens and $T$. harzianum resulted in highest seedling emergence, vigour index, minimum pre emergence rot and post emergence damping off in chilli (Kabdal et al., 2010). Bharathi et al. (2004) reported that mixed bioformulation of $P$. fluorescens $(\mathrm{pf} 1)+B$. subtilis+neem+chitin was found to be the best for reducing the fruit rot incidence of chilli besides increasing the plant growth and yield parameters under both greenhouse and field conditions. The treatment combination of $T$. viride $+P$. fluorescens was most effective in reducing the incidence of seedling rot and increasing plant growth and yield in chilli grown under greenhouse as well as field conditions (Ngullie and Daiho, 2013). Similarly, combined application of bioagents like Serratia quinivorans, Enterobacter ludwigii, Lysinibacillus sphaericus, Aeromonas media and Pseudomonas poae increased plant height, diameter of the stem, number of fruits in capsicum (Vyas and Vyas, 2014; Avendano et al., 2014). Indigenous isolates of $T$. viride -16 and $T$. viride were best in terms of disease suppression without affecting germination of seeds (Rani et al., 2009). Plant height, top root length, stem girth and weight of coffee seedlings increased upon combined inoculation of bioagents like Azospirillum brasilense, Glomus fasciculatum and P-solubilizing Pseudomonas striata and Serratia spp. as compared to un-inoculated control (Salakinkop et al., 2003). Plant growth, yield and nutrient uptake of wheat plants increased due to the synergistic effects of Bacillus sp. Azotobacter chroococcum and Glomus fasciculatum (Khan and Zaidi, 2007). Dual inoculants i.e. Bacillus megaterium and Trichoderma viride showed maximum shoots and roots dry matter, increased root length and seedlings height in chilli and tomato (Hayyan et al., 2009; Morsy et al., 2009).

\section{Effect of PGPR and BCAs as Seed Treatment and Soil Application on Crop Production}

Application of bioagents through seed treatment as well as soil application has also been advocated as a better option over the single method of their inoculation. Raja et al. (2013) have observed that the combination of $T$. harzianum $+P$. fluorescens and $T$. harzianum $+T$. viride were more effective in reducing disease incidence. Highest plant height in chilli was recorded in T. harzianum as compared to other treatment combinations and untreated control in chilli (Kavitha et al., 2005). Seed treatment (talc formulation $10 \mathrm{~g} \mathrm{~kg}^{-1}$ of seed), seedling root dip (talc formulation $20 \mathrm{~g}^{-1}$ ) and soil application (talc formulation $2.5 \mathrm{~kg} \mathrm{ha}^{-1}$ ) significantly improve plant growth due to ISR (Induced Systemic Resistance) in chilli (Sundaramoorthy et al., 2012). T. harzianum (TR20)+P. fluorescens (P28), was most effective in reducing disease incidence and recorded highest yield/plant followed by $T$. pseudokoningii (TR17) $+P$. fluorescens (P51) in chilli (Rini and Sulochana, 2006). Use of talc formulation of $B$. subtilis as soil application, seed treatment, foliar spray and root dip treatment recorded considerable enhancement of all biometric parameters (plant fresh weight, dry weight and root length) and reduced disease incidence 
compared to the untreated control in chilli (Narasimhan and Shivakumar, 2016). Isolates of PGPR applied as seed soaking ( $1 \times 108 \mathrm{cfu} \mathrm{ml}^{-1}$ for $30 \mathrm{~min}$ prior to planting), soil drench ( $5 \mathrm{ml}$ $\times 108$ cfu cup $^{-1}$ ), spray on the surface of soil and adding with irrigation water increased seed germination and seedling height in pepper (Almaghrabi et al., 2014). Whereas, Sang et al. (2012) reported that biocontrol strains (Pseudomonas otitidis YJR27, P. putida YJR92, Tsukamurella tyrosinosolvens YJR102 and Novosphingobium capsulatum YJR107) effectively controlled Phytophthora blight, anthracnose occurrence and enhanced fruit yield in pepper plants under field conditions. Pseudomonas fluorescens strains applied to seed, soil and foliage or as a seedling dip significantly reduced Tomato Spotted Wilt Virus, with a concomitant increase in growth promotion in both under glasshouse and field conditions in tomato (Kandan et al., 2005). PGPR strains (Bacillus megaterium TV-3D, B. megaterium TV-91C, Pantoea agglomerans RK-92, B. subtilis TV-17C, B. megaterium TV-87A, B. megaterium KBA-10) when applied twice as drench into root zone after germination of seed at one week intervals @

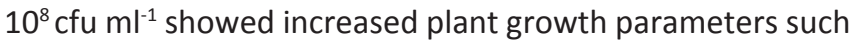
as fresh shoot weight, dry shoot weight, root diameter, root length, fresh root weight, dry root weight, plant height, stem diameter, leaf area and chlorophyll contents of cauliflower transplants (Ekinci et al., 2014).

\section{Conclusion}

The ability of PGPRs, BCAs and antibiotics produced by them to suppress phytopathogens can be of significant agronomic importance. These might be useful in formulating new inoculants, offering an alternative of eco-friendly biological control of plant diseases and improving crop production.

\section{References}

Alagawadi, A.R., Krishnaraj, P.U., 1998. Field performance of two local rhizobacteria isolates in sorghum. $37^{\text {th }}$ Annual Conference of Association of Microbiologists on India, Mangalore, 278.

Almaghrabi, O.A., Abdelmoneim, T.S., Albishri, H.M., Moussa, T.A.A., 2014. Enhancement of maize growth using some plant growth promoting rhizobacteria (PGPR) under laboratory conditions. Life Science Journal 11, 764-772.

Alwathnani, H.A., Pervee, K., 2012. Biological control of fusarium wilt of tomato by antagonist fungi and cyanobacteria. African Journal of Biotechnology 11, 1100-1105.

Amin, M., Fitsum, S., Selvaraj, T., Mulugeta, N., 2014. Field management of anthracnose (Colletotrichum lindemuthianum) in common bean through fungicides and bioagents. Advances in Crop Science and Technology 2, 124.

Asaduzzaman, M., Alam, M.J., Islam, M.M., 2010. Effect of Trichoderma on seed germination and seedling parameters of chilli. Journal of Science Foundation 8,
141-150.

Avendano, E.G., Rodrigue,z M.L., Aguilar, O.P., Andreu, L.G.I., Trigos, A., Hernandez, M.J.M., 2014. Effect of Rhizobacteria Indole producing on the Development of Capsicum annuum var. jalapeno M. International Research Journal of Biological Sciences 3, 22-27.

Balasubramaniam, A., Kumar, K., 1989. Influence of Azospirillum biofertilizer on rice crop. International Workshop and Symposium on Biological Nitrogen Fixation Associated with Rice Production, CRRI, Cuttack, December 28, 1988 to January 1, 1989.

Bashan, Y., Bashan, L.E., 2002. Protection of tomato seedlings against infection by Pseudomonas syringae pv. tomato by using the plant growth promoting bacterium Azospirillum brasilense. Applied and Environmental Microbiology 68, 2637-2643.

Bharathi, R., Vivekananthan, R., Harish, S., Ramanathan, A., Samiyappan, R., 2004. Rhizobacteria based bioformulations for the management of fruit rot infection in chillies. Crop Protection 23, 835-843.

Bhuvaneswari, G., Reetha, S., Sivaranjani, R., Ramakrishnan, K., 2014. Effect of AM fungi and Trichoderma species as stimulations of growth and morphological character of chilli (Capsicum annuum L.). International Journal of Current Microbiology and Applied Sciences 3, 447-455.

Casanovas, E.M., Barassi, C.A., Sueldo, R.J., 2000. Azospirillum inoculation of maize seeds during imbibition. Cereal Research Communications 28, 25-32.

Dashti N., Zhang, F., Hynes, R., Smith, D.L., 1997. Application of plant growth promoting rhizobacteria to soybean (Glycine max L.) increases protein and dry matter yield under short-season conditions. Plant and Soil 188, 33-41

Datta, M., Palit, R., Sengupta, C., Pandit, M.K., Banerjee, S., 2011. Plant growth promoting rhizobacteria enhance growth and yield of chilli (Capsicum annuum L.) under field conditions. Australian Journal of Crop Science 5, 531-536.

Dibypaul, P.J., Sharma, J.Y.R., Anadraj, M., 2005. Rhizospheric Psuedomonas fluorescens as rejuvenating and root proliferation agent in black pepper. Journal of Biological Control 19, 173-178.

Diniz, K.A., Silva, P-de-A., Oliveira, J.A., Evangelista, J.R.E., 2009. Sweet pepper seed responses to inoculation with microorganisms and coating with micronutrients, amino acids and plant growth regulators. Science and Agriculture 66, 293-297.

Duc, N.H., Mayer, Z., Pek, Z., Helyes. L., Posta, K., 2017. Combined inoculation of arbuscular mycorrhizal fungi, pseudomonas fluorescens and Trichoderma spp. for enhancing defense enzymes and yield of three pepper cultivars. Applied Ecology and Environmental Research 15, 1815-1829.

Ekinci, M., Turan, M., Yildirim, E., Gunes, A., Kotan, R., Dursun, A., 2014. Effect of plant growth promoting 
rhizobacteria on growth, nutrient, organic acid, amino acid and hormone content of cauliflower (Brassica oleracea L. var. botrytis) transplants. Acta Scientiarum Polonorum Hortorum Cultus 13, 71-85.

Gholami, A., Shahsavani, S., Nezarat, S., 2009. The effect of plant growth promoting rhizobacteria (PGPR) on germination, seedling growth and yield of maize. International Journal of Agricultural and Biosystems Engineering 3, 1015-1020.

Girish, N., Umesha, S., 2005. Effect of plant growth promoting rhizobacteria on bacterial canker of tomato. Archives of Phytopathology and Plant Protection 38, 235-243.

Glala, A.A., Ezzo, M.I., Abdalla, A.M., 2010. Influence of plant growth promoting rhizosphere-bacteria (PGPR) enrichment and some alternative nitrogen organic sources on tomato. Acta Horticulturae 852, 131-138.

Glick, B.R., 1995. The enhancement of plant growth by free living bacteria. Canadian Journal of Microbiology 41, 109-117.

Gupta, S., Kaushal, R., Kaundal, K., Chauhan, A., Spehia, R.S., 2015. Efficacy of indigenous plant growth promoting rhizobacteria on capsicum yield and soil health. Research on Crops 16, 123-132.

Hafeez, F.Y, Yasmin, S., Ariani, D., Mehhood, R., Zafar, Y., Malik, K.A., 2006. Plant growth promoting bacteria as biofertilizer. Agronomical Sustainable Development 26, 143-150.

Hajieghrari, B., Torabi-Giglou, M., Mohammadi, M.R., Davari, M., 2008. Biological potantial of some Iranian Trichoderma isolates in the control of soil borne plant pathogenic fungi. African Journal of Biotechnology 7 , 967-972.

Hayyan, I.A.T., Osman, M.B., Hamid, A.A., Yusoff, W.M.W., 2009. Development of microbial inoculants and the impact of soil application on rice seedlings growth. American Journal of Agricultural and Biological Sciences 4, 79-82.

Hessenmeller, A., Zeller, W., 1996. Biological control of borne Phytophthora sp. in strawberry with bacterial antagonists, antagonistic effect and colonization of rhizospore. Zeitschruft- furpflan zenterankheiten-undpflanzen schhuts 103, 602-609.

Hou, M.P., Oluranti, B.O., 2013. Evaluation of plant growth promoting potential of four rhizobacterial species for indigenous system. Journal of Central South University 20, 164-171.

Ibiene, A.A., Okerentugba, P.O., Akhigbemen, O.J., 2013. Effect of Some Plant growth promoting rhizobacteria (PGPR) on growth of Piper nigra. Stem Cell 4, http:// www.sciencepub.net/stem.

Jarak, M., Mrkovacki, N., Bjelic, D., Josic, D., Hajnal-Jafari, T., Stamenov, D., 2012. Effects of plant growth promoting rhizobacteria on maize in greenhouse and field trial. African Journal of Microbiology Research 6, 5683-5690.
Jourdan, E., Ongena, M., Adam, A., Thonart, P., 2007. PGPRinduced systemic resistance: activity of amphiphilic elicitors and structural analogues on different plant species. Bulletin-OILB/SROP 30, 123-126.

Kabdal, P., Hooda, K.S., Joshi, D., Hedau, N.K., Pandey, K.N., 2010. Biocontrol agents in the health management of capsicum nursery. Indian Journal of Horticulture 67, 70-72.

Kanchana, D., Jayanthi, M., Usharani, G., Saranraj, P., Sujitha, D., 2014. Interaction effect of combined inoculation of plant growth promoting rhizobacteria on growth and yield parameters of chilli variety $\mathrm{K} 1$ (Capsicum annuum L.). International Journal of Microbiological Research 5, 144-151.

Kandan, A., Ramiah, M., Vasanthi, V.J., Radjacommare, R., Nandakumar, R., Ramanathan, A., Samiyappan, R., 2005. Use of Pseudomonas fluorescens based formulations for management of tomato spotted wilt virus (TSWV) and enhanced yield in tomato. Biocontrol Science and Technology 15, 553-569.

Kavitha, K., Mathiyazhagan, S., Senthilvel, V., Nakkeeran, S., Chandrasekar, G., 2005. Development of bioformulations of antagonistic bacteria for the management of damping off of chilli (Capsicum annuum L.). Archives of Phytopathology and Plant Protection 38, 19-30.

Khalid, A., Arshad, M., Zahir, Z.A., 2004. Screening plant growth promoting rhizobacteria for improving growth and yield of wheat. Journal of Applied Microbiology 96, 473-480.

Khan, M.S., Zaidi, A., 2007. Plant growth promoting rhizobacteria from rhizosphere of wheat and chickpea. Annals of Plant Protection Sciences 10, 265-271.

Kokalis, B.N., Vavrina, C.S., Rosskopf, E.N., Shelby, R.A., 2002. Field evaluation of plant growth-promoting rhizobacteria amended transplant mixes and soil solarization for tomato and pepper production in Florida. Plant and Soil 238, 257-266.

Kumar, K., Amaresan, N., Madhuri, K., Gautam, R.K., Srivasatava, R.C., 2011. Isolation and characterization of plant growth promoting bacteria and their effect on chilli (Capsicum annuum L.) seedling growth. In: Plant growth-promoting rhizobacteria (PGPR) for sustainable agriculture. Proceedings of the $2^{\text {nd }}$ Asian PGPR Conference, Beijing P R China, 93-101.

Kumar, S., Arya, M.C., Singh, R., 2010. Management of sweet pepper diseases and growth promotion by Pseudomonas fluorescens and Trichoderma harzianum in mid hills of central himalayas, India. Indian Phytopathology 63, 181-186.

Kushwaha, M., Verma, A.K., 2014. Antagonistic activity of Trichoderma spp, (a bio-control agent) against isolated and identified plant pathogens. Internationl Journal of Chemical and Biological Sciences 1, 1-6.

Lamsal, K., Kim, S.W., Kim, Y.S., Lee, Y.S., 2012. Application 
of rhizobacteria for plant growth promotion effect and biocontrol of anthracnose caused by Colletotrichum acutatum on pepper. Mycobiology 40, 244-251.

Mandyal, P., Kaushal, R., Sharma, K., Kaushal, M., 2012. Evaluation of native PGPR isolates in bell pepper for enhanced growth, yield and fruit quality. International Journal of Farm Sciences 2, 28-35.

Mangmang, J.S., Deaker, R., Rogers, G., 2014. Effects of plant growth promoting rhizobacteria on seed germination characteristics of tomato and lettuce. Journal of Tropical Crop Science 1, 34-40.

Mehetre, S.T., Kale, S.P., 2011. Bacillus licheniformis (NR1005) and antagonistic fungi, Trichoderma harzianum to control Pythium aphanidermatum-induced damping off in chilli (Capsicum annuum L.). Archives of Phytopathology and Plant Protection 44, 1068-1074.

Morsy, E.M., Abdel-Kawi, K.A., Khalil, M.N.A., 2009. Efficiency of Trichoderma viride and Bacillus subtilis as biocontrol agents against Fusarium solani on tomato plants. Egyptian Journal of Phytopathology 37, 47-57.

Naik, M.K., Manjunatha, H., Amaresh, Y.S., Hosmani, A.K., Bheemanna, M., Reddy, M.S., Sudha, S., Chennappa, G., Sreenivas, A.G., 2011. Interactions between PGPRs and crops with special reference to chilli (Capsicum annuum L.). In: Plant growth-promoting rhizobacteria (PGPR) for sustainable agriculture. Proceedings of the $2^{\text {nd }}$ Asian PGPR Conference, Beijing P R China, 159-163.

Narasimhan, A., Shivakumar, S., 2016. Biocontrol of Rhizoctonia solani root rot of chilli by Bacillus subtilis formulations under pot conditions. Journal of Biological Control 30, 109-118.

Ngullie, M., Daiho, L., 2013. Efficacy of biocontrol agents in controlling Rhizoctonia solani on naga king chilli (Capsicum chinense Jacq.). Journal of Experimental Biology and Agricultural Sciences 1, 197-201.

Nirmala, C.P., Sharma, A., Dubey, R.C., Maheshwari, D.K., 1999. Psuedomonas aeruginosa (GRG) as a strong antagonist of Macrophomina phaseolina and Fusarium oxysporum. Cytobios 99, 185-189.

Noumavo, P.A., Kochoni, E., Didagbe, Y.O., Adjanohoun, A., Allagbe, M., Sikirou, R., Gachomo, E.W., Kotchoni, S.O., Baba-Moussa, L., 2013. Effect of different plant growth promoting rhizobacteria on maize seed germination and seedling development. American Journal of Plant Sciences 4, 1013-1021.

Olabiyi, T.I., Ruocco, M., 2013. In-vitro competition bio assay experiment on the effect of Trichoderma species and some crop pathogenic fungi. Journal of Biology, Agriculture and Healthcare 3, 115-120.

Olawumi, I.O., Christopher, A., Salami, Olusola, A., 2016. The interactive effects of three Trichoderma species and damping-off causative pathogen Pythium aphanidermatum on emergence indices, infection incidence and growth performance of sweet pepper.
International Journal of Recent Scientific Research 7, 10339-10347.

Raj, T.S., Christopher, D.J., 2009. Effect of bio-control agents and fungicides against Colletotrichum capsici causing fruit rot of chilli. Annals of Plant Protection Sciences 17, 143-145.

Raja, Abhilasha, A.L., Simon, S., Basayya, N., 2013. Management of seedling rot of chilli (Capsicum annuum L.) using Trichoderma spp. and Pseudomonas fluorescens. Annals of Plant Protection Sciences 21, 387-390.

Rani, G.S.D., Naik, M.K., Patil, M.B., Prasad, P.S., 2009. Biological control of Fusarium solani causing wilt of chilli. Indian Phytopathology 62, 190-198.

Rather, S.A., Hussain, M.H., Sharma, M.L., 2010. Effect of biofertilizers on growth yield and economics of field pea (Pisum sativum L.). International Journal of Agricultural Science 6, 65-66.

Rini, C.R., Sulochana, K.K., 2006. Management of seedling rot of chilli (Capsicum annuum L.) using Trichoderma species and fluorescent Pseudomonads (Pseudomonas fluorescens). Journal of Tropical Agriculture 44, 79-82.

Saharan, B.S., Nehra, V., 2011. Plant growth promoting rhizobacteria: A critical review. Life Sciences and Medicine Research, 1-30.

Salakinkop, S.R., Shivaprasad, P., Raghuramulu, Y., Paneer, S.P., 2003. Bio inoculation for improving the vigour of coffee seedlings. $6^{\text {th }}$ International PGPR Workshop October 5-10, 2003 Calicut, India.

Sang, M.K., Shrestha, A., Kim, Du-Y., Park, K., Pak, C.H., Kim, K.D., 2012 Biocontrol of phytophthora blight and anthracnose in pepper by sequentially selected antagonistic rhizobacteria against Phytophthora capsici. Journal of Plant Pathology 29, 154-167.

Sengupta, C., Bhosale, A., Malusare, S., 2015. Effect of plant growth promoting rhizobacteria on seed germination and seedling development of Zea mays L. International Journal of Research in Advent Technology (E-ISSN: 23219637), Special Issue National Conference "ACGT 2015.

Shahid, M., Srivastava, M., Singh, A., Kumar, V., Rastogi, S., Pathak, N., Srivastava, A., 2014. Comparative study of biological agents, Trichoderma harzianum (ThAzad) and Trichoderma viride (01PP) for controlling wilt disease in pigeon pea. Journal of Microbial and Biochemical Technology 6, 110-115.

Sriram, S., Manasa, S.B., Savitha, M.J., 2009. Potential use of elicitors from Trichoderma in induced systemic resistance for the management of Phytophthora capsici in red pepper. Journal of Biological Control 23, 449-456.

Stefan, M., Munteanu, N., Stoleru, V., Mihasan, M., 2013. Effects of inoculation with plant growth promoting rhizobacteria on photosynthesis, antioxidant status and yield of runner bean. Romanian Biotechnological Letters $18,8132-8142$. 
Suh, J.S., Balaraju, K., Cho, Y.E., Park, J.W., Lee, S.W., Park, K., 2011. Biological control of Phytophthora capsici and Colletotrichum acutatum by a PGPR strain Bacillus subtilis KP07 on red-pepper. In: Plant growth-promoting rhizobacteria (PGPR) for sustainable agriculture. Proceedings of the $2^{\text {nd }}$ Asian PGPR Conference, Beijing P R China, 351.

Sunaina, V., Ajay, S., 2005. Effect of plant growth promoting rhizobacteria on black scurf disease of potato and ability to promote their growth. Journal of Biological Control 19, 47-50.

Sundaramoorthy, S., Raguchander, T., Ragupathi, N., Samiyappan, R., 2012. Combinatorial effect of endophytic and plant growth promoting rhizobacteria against wilt disease of Capsicum annum L. caused by Fusarium solani. Biological Control 60, 59-67.

Suryanto, D., Patonah, S., Munir, E., 2010. Control of Fusarium wilt of chilli with chitinolytic bacteria. Hayati Journal of Biosciences 17, 5-8.
Turan, M., Ekinci, M., Yildirim, E., Guneş, A., Karagoz, K.R.K., Dursun, A., 2014. Plant growth promoting rhizobacteria improved growth, nutrient, and hormone content of cabbage (Brassica oleracea) seedlings. Turkish Journal of Agriculture and Forestry 38, 327-333.

Violante, H.G., Portugal, V.O., 2007. Alteration of tomato fruit quality by root inoculation with plant growth-promoting rhizobacteria (PGPR): Bacillus subtilis BEB-13bs. Scientia Horticulturae 113, 103-106.

Vyas, M., Vyas, A., 2014. Field response of Capsicum annuum dually inoculated with AM fungi and PGPR in western Rajasthan. International Journal of Research Studies in Biosciences 2, 21-26.

Zhang, F., Yuan, J., Yang, X., Cui, Y., Chen, L., Ran, W., Shen, Q., 2013. Putative Trichoderma harzianum mutant promotes cucumber growth by enhanced production of indole acetic acid and plant colonization. Plant and Soil 368, 433-444. 